\title{
カオリンー長石系素地の焼き締り過程に関する研究
}

\author{
李 應 相・浜 野 健 也 \\ (東京工業大学 工業材料研究所)
}

\section{Studies on the Densification Process of Kaolin-Feldspar Bodies}

\author{
By \\ Eung Sang LEE and Kenya HAMANO \\ (Research Laboratory of Engineering Materials, Tokyo Institute of Technology)
}

\begin{abstract}
Densification processes of the bodies consisting of kaolin and feldspar were investigated kinematically by means of isothermal shrinkage measurement, and microstructurally by $\mathrm{X}$ ray diffraction method and observation with polarization microscope and scanning electron microscope.

Results of thermal shrinkage measurement of the specimens showed three distinct shrinkages occurred at about $500^{\circ}, 900^{\circ}$ and $1100^{\circ} \mathrm{C}$ or higher temperatures. The shrinkage occurred at about $500^{\circ} \mathrm{C}$ seemed to be caused by the decomposition of kaolin minerals, so that the shrinkage decreased with the increase of feldspar content of the bodies. The shrinkage observed at about $900^{\circ} \mathrm{C}$ seemed to occur with diffusion sntering process of metakaolin grain boundary. Apparent activation energy of the shrinkage process was increased with the increase of the feldspar content. The increase might be caused by interruption of the grain boundary diffusion with the presence of feldspar particles incorporated into the bodies. The rate constant of the shrinkage process at $900^{\circ} \mathrm{C}$ decreased with the increase of the feldspar content. The decrese seemed to be interpreted by the decrease of metakaolin content in the bodies.

The shrinkage observed at about $1100^{\circ} \mathrm{C}$ might be associated with densification processes occurred by viscous flow of spinel type intermediate phase grains with small amount of the melt formed from a little impurities contained in the kaolin and feldspar fine particles. Apparent activation energy for the shrinkage process increased appreciably with the increase of feldspar content. The increase seemed to be caused by the increase of fusion products of the feldspar with rising temperature. The rate constant of the shrinkage process at $1060^{\circ} \mathrm{C}$ was increased with the increase of feldspar content. The increase seemed to be caused by the same reason mentioned just above.

It was inferred that the shrinkage occurred at higher temperatures than $1100^{\circ} \mathrm{C}$ was also caused by the viscous flow mechanism. The shrinkage diminished when most pores in the body were closed in the glassy matrix. When the bodies were fired at $1500^{\circ} \mathrm{C}$, all bodies showed bloating, that is, the bodies became an over firing stage. Further, changes of the constituent minerals and microstructure of the bodies with the densification process were described.
\end{abstract}

[Received April 15, 1972]

\section{1. 緒言}

陶磁器素地の焼き締り過程を定量化する基礎資料を得 るため, すでにカオリン単味素地 ${ }^{11}$ およびカオリン一石 英系素地 ${ }^{2)}$ について検討を行ない，これらの天然原料を 用いた複雑な素地についても速度論的な検討が可能であ ることを示した。

カオリンや石英から成る素地は，不純物を無視して考 えると $\mathrm{Al}_{2} \mathrm{O}_{3}-\mathrm{SiO}_{2}$ 二成分系から成るため, 平衡状態に おいても $1595^{\circ} \mathrm{C}$ まで熔融物を生成しないので焼き締め
にくい, そのため陶磁器素地には, 比較的低温度で熔融 物を生成するような媒熔材原料を配合する。この目的で 最も広く使われているのはカリ長石である。カオリンに カリ長石を配合すると化学成分的には $\mathrm{K}_{2} \mathrm{O}-\mathrm{Al}_{2} \mathrm{O}_{3}-\mathrm{SiO}_{2}$ 三成分系となるため, 平衡状態では $980^{\circ} \mathrm{C}$ 付近の低温 度で熔融物が生成するようになり, 低い温度範囲から焼 き締りが促進されるようになる。このような長石の添加 は工業的比古くから行なわれているが，この添加がカ オリンの焼き締りの過程に対してどのように作用するか 
Table 1. Chemical compositions of the raw materials. (\%)

\begin{tabular}{llllllllllr}
\hline & $\mathrm{SiO}_{2}$ & $\mathrm{TiO}_{2}$ & $\mathrm{Al}_{2} \mathrm{O}_{3}$ & $\mathrm{Fe}_{2} \mathrm{O}_{3}$ & $\mathrm{MnO}$ & $\mathrm{CaO}$ & $\mathrm{MgO}$ & $\mathrm{Na}_{2} \mathrm{O}$ & $\mathrm{K}_{2} \mathrm{O}$ & $\mathrm{Ig}$. loss \\
\hline Hadong kaolin $(24 \mathrm{~h}$ grinding) & 45.81 & 0.09 & 38.45 & 0.70 & $\mathrm{tr}$ & 0.35 & 0.25 & & 1.14 & 13.21 \\
Indian potash feldspar $(<10 \mu)$ & 65.24 & 0.0 & 18.96 & 0.06 & - & 0.1 & 0.0 & 2.66 & 12.43 & 0.24 \\
\hline
\end{tabular}

という問題についてはまだ明らかにされていない点が多 い. 本研究では主としてカオリン素地の焼き締り過程に 対するカリ長石添加の影響を検討した。

\section{2. 使用原料および前処理}

カオリンはすでに報告したものと同じ，韓国河東産カ オリン水箕物を $24 \mathrm{~h}$ アルミナ製ポットミルで湿式粉砕 したもので，その化学分析值は 表-1 に，また粒度分布 は 図-1 に示した. 組成鉱物はカオリナイト, 加水八口 イサイトを主体とし，少量雲母質粘土鉱物をともない， さらにわずかに石英や長石を含んでいる。長石はインド 産カリ長石を使用した。粗砕後アルミナ製ポットミルで 乾式粉砕し，さらに水箕法によって $10 \mu$ 以下の粒子を 採取した．化学分析值は 表-1 に併記した通りで, ソー ダ分を少量ともならカリ長石であり, 偏光顕微鏡観察か らパーサイト構造を有するものと認められた。粉砕試料 の粒度分布は 図-1 に併記した。

これらの原料を 表-2 に示したように配合した。混合 はアルミナ製ポットミルにゴムボールを使用し，湿式で $24 \mathrm{~h}$ 行なった後, 沪過, 乾燥し, 瑪瑙乳鉢で軽く粉研 してから，金型を用い，油圧プレスで $10 \mathrm{~mm} \times 80 \mathrm{~mm}$ ×約 $5 \mathrm{~mm}$ の棒状に $800 \mathrm{~kg} / \mathrm{cm}^{2}$ の圧力で成形して試験 片とした。また 熱膨脹測定用には別に油圧プレスで 5 $\mathrm{mm} \times 40 \mathrm{~mm} \times$ 約 $5 \mathrm{~mm}$ の棒状に $300 \mathrm{~kg} / \mathrm{cm}^{2}$ の圧力で 予備成形し, さらに $800 \mathrm{~kg} / \mathrm{cm}^{2}$ の圧力で静水圧プレス

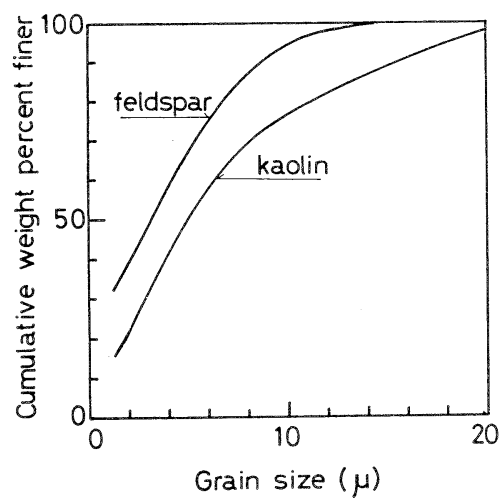

Fig. 1. Grain size distribution curves of the raw materials.

Table 2. Compositions of the kaolin-feldspar bodies. (\%)

\begin{tabular}{lrrrrrc}
\hline No. & 1 & 2 & 3 & 4 & 5 & 6 \\
\hline Kaolin & 99 & 98 & 95 & 90 & 80 & 70 \\
Feldspar & 1 & 2 & 5 & 10 & 20 & 30 \\
\hline
\end{tabular}

成形して試験片を作成した。

\section{3. 昇温熱膨脹・収縮の測定}

まずカオリン一長石系の各素地の焼き締り状態を概略 検討するため，それぞれの試験片について熱膨脹，収縮 の測定を行なった。得られた結果を㘠一に示した。い ずれの素地も図中に併記したカオリン単味素地の場合と 同様に, $500^{\circ} \mathrm{C}$ 付近, $900^{\circ} \mathrm{C}$ 付近および $1100^{\circ} \mathrm{C}$ 以上, と 明らかに区別できる 3 段階の顕著な収縮を示している。 この収縮が起る温度は長石配合量によってほとんど変化 しない。しかし配合量が多くなると，500 C 付近，900 ${ }^{\circ} \mathrm{C}$ 付近の收縮は規則的に小さくなり，また $600^{\circ} \sim 900^{\circ} \mathrm{C}$ 付近のゆるやかな収縮も規則的に小さくなる。これはカ オリンの収縮に, 図中に併記したカリ長石の膨脹が重な るためと思われる。

以上の結果からこの系の素地の焼き締りの過程を上記 の3つの段階に分けて，以下それぞれの段階における収 縮の過程を，等温収縮測定，さらに焼き締り度合，組成 鉱物の変化，微構造組織の変化などを検討することに よって究明した。

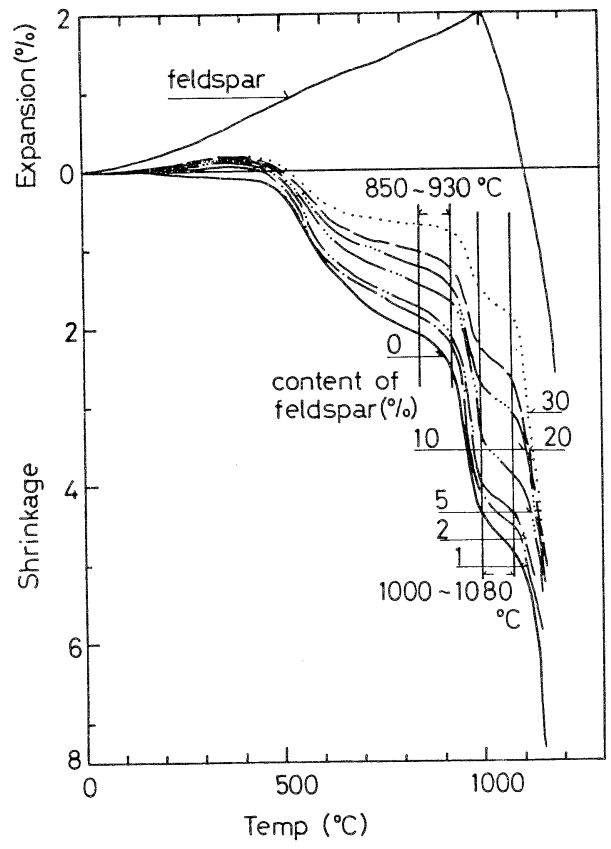

Fig. 2. Thermal expansion and shrinkage curves of bodies consisting of kaolin and feldspar. (heating rate $: 10^{\circ} \mathrm{C} / \mathrm{min}$ ) 


\section{4. $500^{\circ} \mathrm{C}$ 付近で起る収縮についての検討}

この収縮は, カオリン単味素地で認められる収縮と全 く同じ温度範囲で起り，長石配合量が増加すると次第に 小さくなる.この収縮の起る温度範囲では，X線回折結 果から，組成鉱物はカオリンが無定形なメタカオリンと 推定されるものに変るほか，長石には変化がなく，また 偏光顕微鏡および走查型電子顕微鏡観察から，カオリン 部分*と長石粒子とが反応している徴候も認められない． それ故この $500^{\circ} \mathrm{C}$ 付近で起る収縮は，カオリン単味の 場合と同様に，カオリン鉱物の脱水に由来するものと推 定される. 長石配合量が増加すると収縮量が減少するの は，長石配合量が増加するほどカオリン量が減少するた めである。

\section{5. $900^{\circ} \mathrm{C}$ 付近で起る収縮についての検討}

\section{1 等温収縮の測定}

次に $900^{\circ} \mathrm{C}$ 付近で起る収縮過程を検討するため, 等 温收縮の測定を行なった。予備実験の結果から, まず試 験片を $700^{\circ} \mathrm{C}$ で $2 \mathrm{~h}$ 炍燒して, $500^{\circ} \mathrm{C}$ 付近で起る収縮を 完了させた後, $850^{\circ}, 870^{\circ}, 890^{\circ}, 910^{\circ}$ および $930^{\circ} \mathrm{C}$ の 5 点を選んで，それぞれ等温収縮を測定した。得られた収 縮曲線の 1 例を 図-3 に示した。この曲線に対してすで に報告した方法で補正を行なった後，時間と収縮率との 関係を両対数プロットすると，例えば 図-4 のようにな り，良好な直線関係が得られた。他の配合量の素地につ いても同様であり，等温収縮率 $\Delta l / l_{0}$ と保持時間 $t$ と の間に

$$
\left(\Delta l / l_{0}\right)^{p}=B^{\prime} t
$$

の関係が存在していることがわかる。さらにこの初期 の直線の勾配，1/p はいずれもほぼ $0.25 〜 0.35 ， 一$ 部

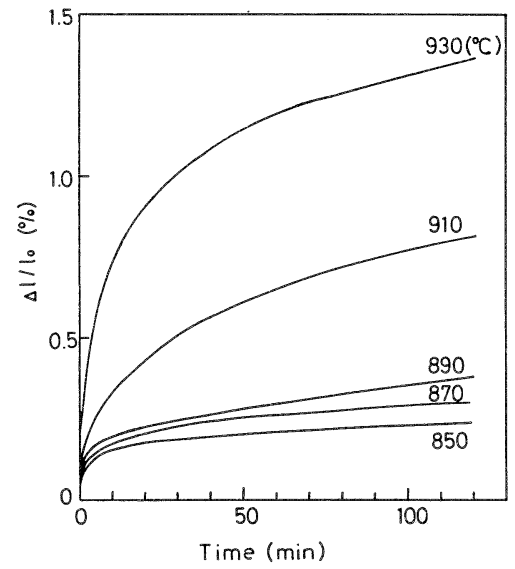

Fig. 3. Isothermal shrinkage curves of bodies consisting of $80 \%$ kaolin and $20 \%$ feldspar at $850^{\circ} \sim 930^{\circ} \mathrm{C}$

*,初めカオリンであった部分を，その状態では変化していて も, “カオリン部分”と略称するとととする。

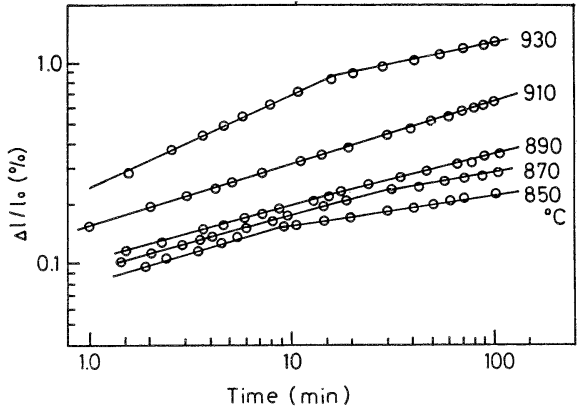

Fig. 4. $\log \Delta l / l_{0}-\log t$ plot of the bodies consisting of $80 \%$ kaolin and $20 \%$ feldspar at $850^{\circ} \sim 830^{\circ} \mathrm{C}$.

0.38〜0.39 の範囲にある。この勾配の值はカオリン単 味拉よびカオリン一石英系素地についての值と大体一致 している。

\section{2 組成鉱物および微構造組織の変化}

次にこの温度範囲で起る収縮の前後での組成鉱物の変 化をX線回折法によって検討した結果，測定前の試料で は配合した長石および不純物の少量の石英のほかメタカ オリンと思われる無定形物が認められるのみで，また $910^{\circ} \mathrm{C}$ 以下の温度では，2h の等温收縮の後の試料も全 く変化していない。 しかし $930^{\circ} \mathrm{C}$ 以上の温度で $2 \mathrm{~h}$ 保 持した後にはスピネル型中間相が生成しているのが認め られる。偏光顕微鏡下でも走査型電子顕微鏡観察の結果 からも，この温度範囲での等温収縮の前後では，幾分緻 密化が進んでいるほかにはほとんど変化は認められな かった。

\section{3 考察}

以上の結果から，この温度範囲では，カオリンはメタ カオリンに変化しているが，このメタカオリンと長石と は互いに反応している徵候は認められず，また等温収縮 測定結果の両対数プロットの直線勾配がカオリン単味素 地の場合とほとんど同じ $0.25 \sim 0.35$ 位の範囲に入るこ と, また長石単味素地ではこの温度範囲で収縮を起さな いことから，この収縮もカオリン単味素地やカオリン一 石英系素地の場合と同様に，メタカオリン粒子の粒界拡 散による焼結にともならものと推定することができる。 長石配合量の多い素地で収縮が少なくなることも，この 収縮がカオリン部分で起っていることを示している.

さらにこの収縮過程について速度定数を算出し，アレ ニウス・プロットすると 図-5 のように，一部乱孔ては いるが，直線関係が得られる。この関係から，この収縮 過程に対する見掛けの活性化エネルギーと度数因子,さ らに参考のため $900^{\circ} \mathrm{C}$ に打ける速度定数值を算出し, 長石配合量に対してプロットすると図-6 のようにな る。值は幾分乱れているが，見掛けの活性化エネルギー 值は，長石量が多くなると大きな值を示すことがわか る.この傾向は石英添加の場合と同じで，その物理的意 
味は明確でないが，多分メタカオリン粒子間に，この温 度ではまだ不活性な長石粒子が大ることによって, 粒界 拡散が阻害されることに関係するのではないかと推定さ れる。参考のために算出した $900^{\circ} \mathrm{C}$ におる速度定数 は長石配合量の多くなるほど急減している。これはカ才 リン量が減少するため, 試験片中でこの機構による焼結 を起こす部分が減少することに関係していると考えら

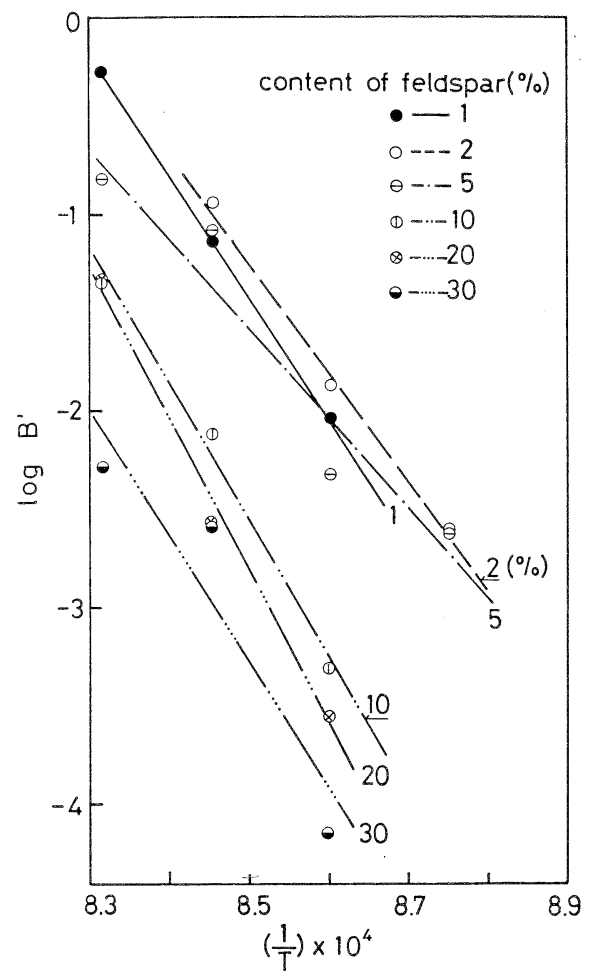

Fig. 5. Arrhenius plots for the shrinkage process occurred around $900^{\circ} \mathrm{C}$ of kaolin-feldspar bodies.

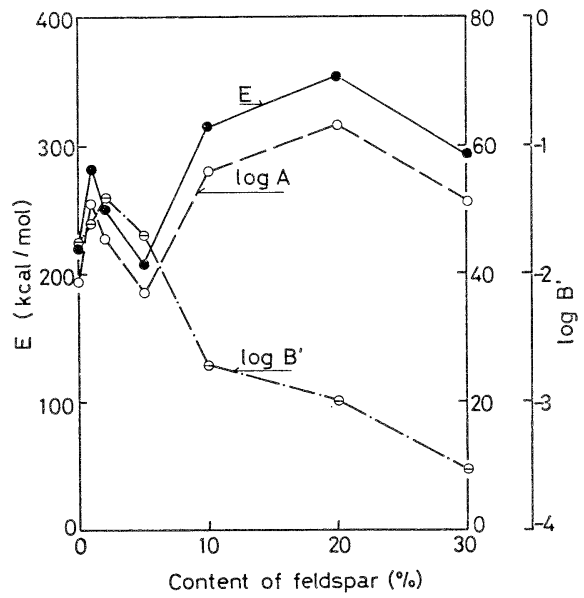

Fig. 6. Apparent activation energy, frequency factor and rate constant at $900^{\circ} \mathrm{C}$ for the shrinkage process occurred around $900^{\circ} \mathrm{C}$ of kaolin-feldspar bodies.
れ，このような長石配合量の影響も，石英配合の場合と 一致している。

$930^{\circ} \mathrm{C}$ 以上になるとスピネル型中間相が生成するよう になるため, 焼結の機構にも変化が起ることが考えられ る. $930^{\circ} \mathrm{C}$ での等温収縮測定結果の両対数プロットの直 線勾配が幾分大きくなり，変化してくるのは，このため と思われる．このように温度が高くなると収縮を起こす 機構が変化してくるとともに，収縮も次第に小さくな る.

\section{6. $1100^{\circ} \mathrm{C}$ 付近で起る収縮についての検討 6.1 等温収縮の測定}

次に $1100^{\circ} \mathrm{C}$ 付近で起る顕著な収縮について，同じよ らにまず等温収縮の測定法によって，その機構を検討し た。試験片は，図-1 の昇温収縮曲線から，長石 1，2\% 配合の試験片については $960^{\circ} \mathrm{C} ， 5 \%$ 以上配合した試験 片については $980^{\circ} \mathrm{C}$ で，それぞれ，あらかじめ $2 \mathrm{~h}$ 炍 焼して，それまでの温度段階で起る収縮を終了させた 後, $1000^{\circ}, 1020^{\circ}, 1040^{\circ}, 1060^{\circ}$ および $1080^{\circ} \mathrm{C}$ の各温 度で等温収縮を測定した。得られた収縮曲線の 1 例を図 -7 に示したが，他の配合量の素地についてもほとんど 同様で，長石配合量が増加するにつれ，特に高温度にな ると収縮が急速に大きくなるのが認められた。これらの 曲線に対して，すでに述べた方法で補正を行ない，時間 と収縮率との関係を両対数にプロットすると図-8の例 のようになり，良好な直線関係が得られた。これらの直 線の, 初期の勾配はいずれもほとんど 1 に近い值とな る.この值はすでに報告したカオリン単味素地やカオリ ン一石英系素地について得られた值と一致している。

\section{2 組成鉱物および微構造組織の変化}

この温度範囲で起る収縮の前後での組成鉱物をX線回 折法で検討した。収縮開始前のものには長石，不純物の 少量の石英およびスピネル型中間相が認められ, 収縮後

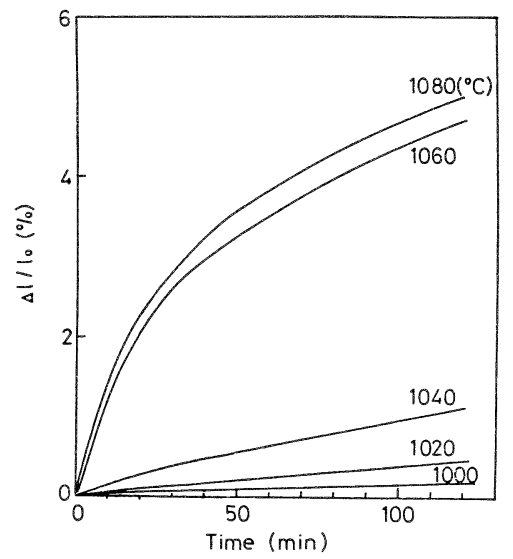

Fig. 7. Isothermal shrinkage curves of bodies consisting of $80 \%$ kaolin and $20 \%$ feldspar at $1000^{\circ} \sim 1080^{\circ} \mathrm{C}$. 


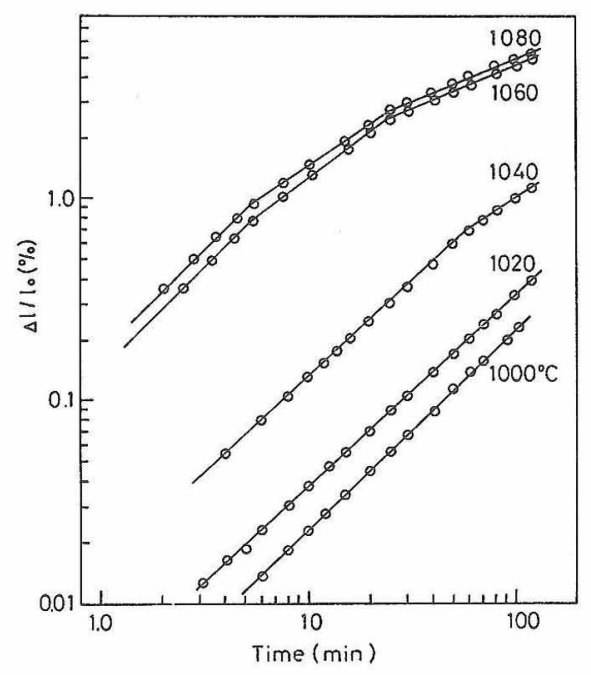

Fig. 8. $\log A l / l_{0}-\log t$ plot of the bodies consisting of $80 \%$ kaolin and $20 \%$ feldspar at $1000^{\circ} \sim 1080^{\circ} \mathrm{C}$.
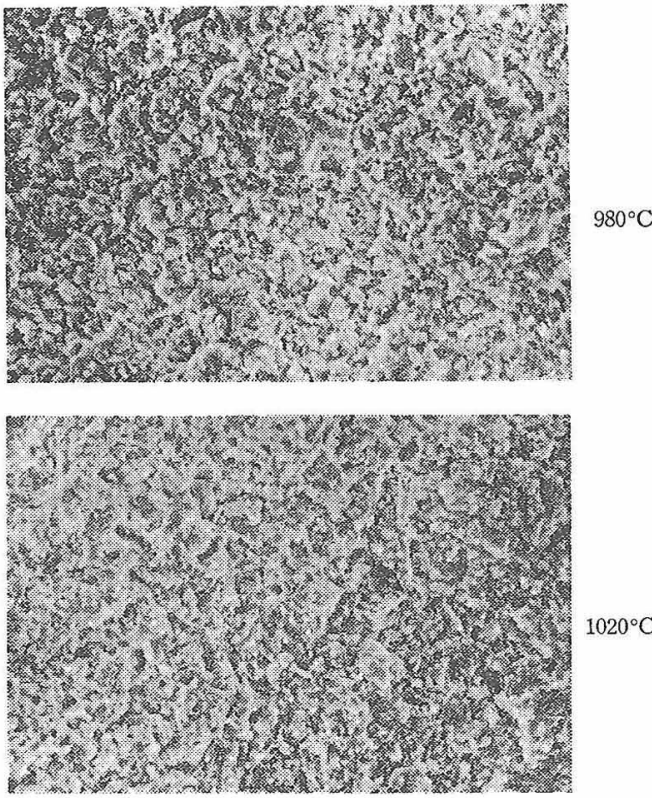

$1020^{\circ} \mathrm{C}$

Fig. 9. Scanning electron-microphotographs of test specimen bodies consisting of $80 \%$ kaolin and $20 \%$ feldspar, after $2 \mathrm{~h}$ soaking of the isothermal shrinkage measurement.

の試料でも長石の量が減少しているのみで，そのほかに は活とんど変化が認められなかった。また試験片の偏光 顕微鏡観察から，すでにこの温庤䉇囲で，少量のガラス が生成しているのが認められ，また試験片破面の走查型 電子顕微鏡観察でも，図-9 亿示したように，収縮測定 後の試料の粒子は全体に丸味を帯びており，部分的には 熔融物が生成していたことが推定される。

\section{3 考察}

この温度範囲で起る収縮過程は，X線回折扔よび微構
造観察の結果から試験片中に熔融物が存在していること が認められ，また等温收縮測定の結果からも勾配がほと んど 1 に近く，Frenkel ${ }^{3)}$ にっって導がれた粘性流動に よる焼結のモデルから誘導された収縮速度式の関係と一 致することになり，結局カオリン単味素地の場合と同様 に，熔融物の作用による粘性流動的な機構による緻密化 過程であるらと推定される. 長石の配合量が増加するに つれ，特に高温度では収縮率が著しく増大寸るが，これ は高温度になるほど長石の熔融によって生成する熔融物 の量が増えるので，粘性流動がより一層顕著に進行する ようになるためと思われる。

さらにこの収縮過程に対する速度定数を算出し，これ をアレニウス・プロットすると図-10のような，乱れて はいるが，ほぼ直線とみなせる関係が得られた。この関 係功この段階の収縮過程に対する見掛けの活性化エネ ルギーと度数因子を算出し，長石配合量に対してプロッ トすると図-11のようになり，長石を少量配合するとこ れらの值は幾分小さくなるが，それ以上長石量が増加す ると值は急速に大きくなる傾向がある。このことは長石 配合量が多いほど，收縮速度定数の温度依存性が大きく なることでもあるが，これは先に述べたように，長石配 合量の多い素地ほど，高温度でこの長石が熔けて熔融物 の量が増加する割合が大きくなることと関係しているよ うである。

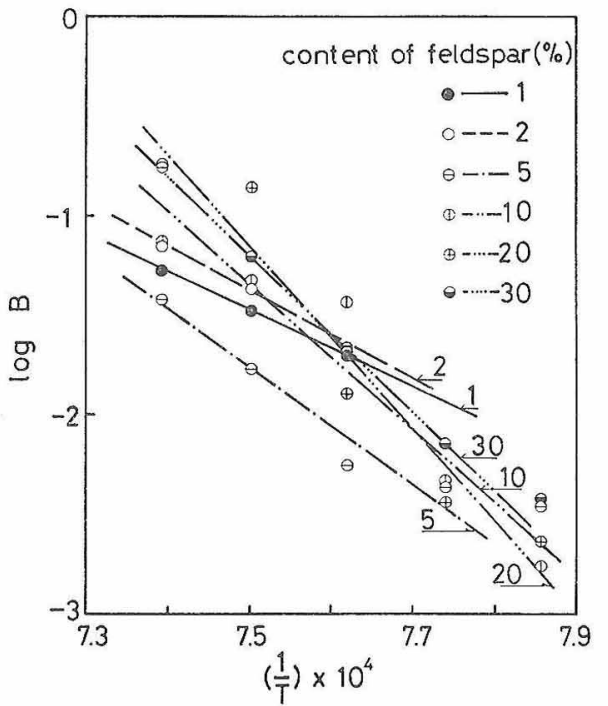

Fig. 10. Arrhenius plots for shrinkage process occurred around $1100^{\circ} \mathrm{C}$ of kaolin-feldspar bodies.

さらに参考のために $1060^{\circ} \mathrm{C}$ における速度定数を 四一 11 中にプロットしたが，この值は素地の長石配合量が 多いほど大きくなる傾向を示す．この傾向は石英添加の 場合と逆になっているが，長石配合量が多いほど，長石 粒子自体が熔けることによって素地の粘性流動を促進す ることを示しているものと思われる。 


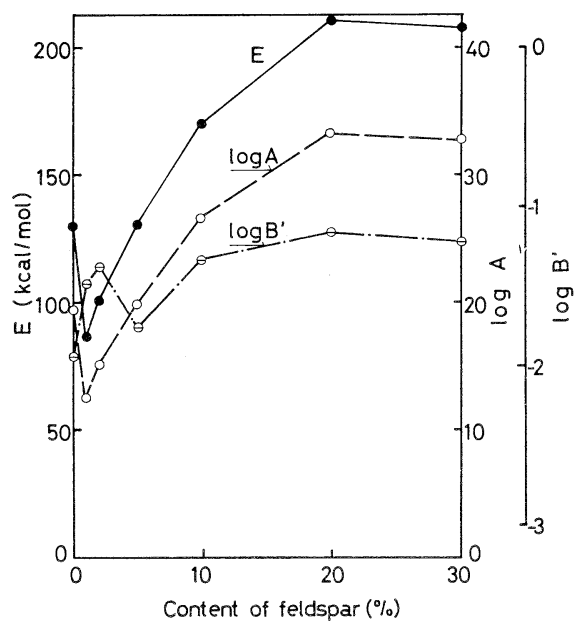

Fig. 11. Apparent activation energy, frequency factor and rate constant at $1060^{\circ} \mathrm{C}$ for shrinkage process occurred around $1100^{\circ} \mathrm{C}$ of kaolinfeldspar bodies.

結局この温度範囲で起る収縮は, 素地中のカオリン部 分, さらに主として長石粒子熔融物の作用に関係する粘 性流動に基づくもので，高温度になるほど長石の熔ける 量が増加するため，この粘性流動が促進される。その効 果はこの収縮過程に対する速度定数の温度依存性を表わ す，見掛けの活性化エネルギーの増大となって認められ ることなどがわかった。

\section{7. $1100^{\circ} \mathrm{C}$ 以上の高温度範囲における緻密化}

前章で述べた収縮に引続いて， $1100^{\circ} \mathrm{C}$ 以上の高温度 になると，さらに急激な収縮が起っているが，この収縮 は余り急激なため，前章までのような速度論的な検討が できなかったので，その緻密化を，焼成素地の焼き締り の度合，組成鉱物，微構造組織の変化から検討した。

\section{1 焼成素地の焼き締り度合}

各配合素地の成形試験片を，電気炉を用い，1100 $1500^{\circ} \mathrm{C}$ の $100^{\circ} \mathrm{C}$ 間隔の各温度に, $6^{\circ} \mathrm{C} / \mathrm{min}$ の速度で加 熱し，それぞれ $2 \mathrm{~h}$ 保持した後， $1000^{\circ} \mathrm{C}$ までは $6^{\circ} \mathrm{C} /$ min, その後さらにゆっくりと炉冷し，種々の測定に供 した.

ます，試験片の長さ方向で測定した線収縮率の結果を 図-12 に示した。值は 5 個の測定值の平均である。カ才 リン単味の素地は $1500^{\circ} \mathrm{C}$ をで焼成温度の上昇とともに 收縮率が増大するが，長石を配合した素地はいずれも $1400^{\circ} \mathrm{C}$ で収縮率が最大となった後, $1500^{\circ} \mathrm{C}$ になると逆 に減少する。この減少は長石配合量の多いものほど著し い.また収縮率は $1200^{\circ} \sim 1400^{\circ} \mathrm{C}$ の間では，1\%の長石 の添加によって相当に増加する，そして $1500^{\circ} \mathrm{C}$ の場合 を除き，長石配合量とともに幾分増加するのみである が， $1500^{\circ} \mathrm{C}$ になると逆に相当顕著に減少する。

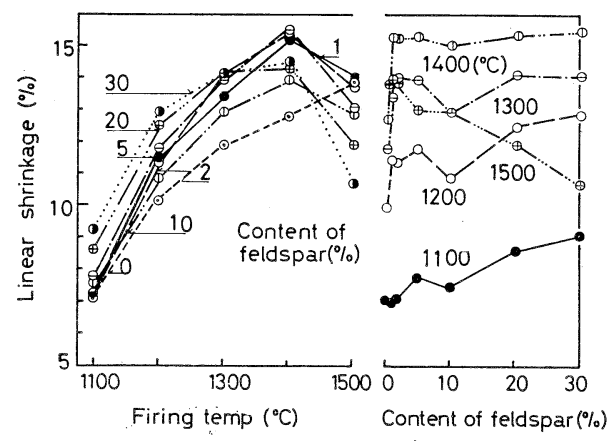

Fig. 12. Linear firing shrinkage of the fired specimens consisting of kaolin and feldspar.

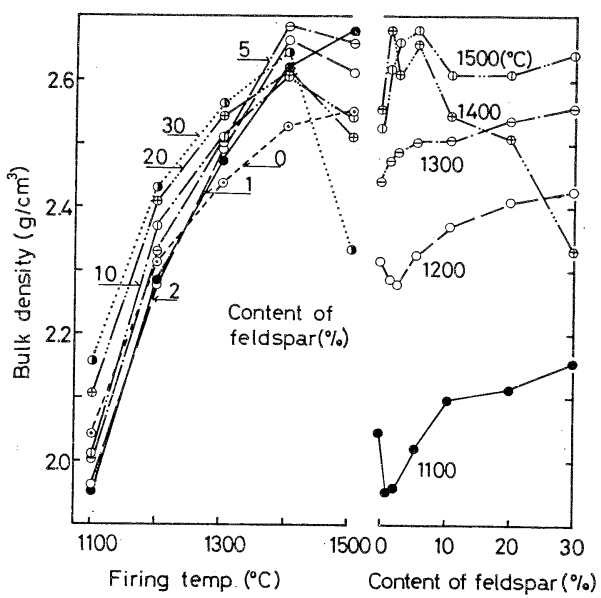

Fig. 13. Bulk density of the fired specimens consisting of kaolin and feldspar.

また嵩比重の測定結果は図-13に示したが，燒成収縮 率の測定結果とほとんど一致していることがわかる。図 -14 は見掛け気孔率の測定結果をまとめたものである. いずれの素地も焼成温度の上昇とともに見掛け気孔率は 著しく減少する。これを同一温度で比較すると長石配合 量の多くなるほど小さくなり, 長石 $20,30 \%$ 配合のもの では $1300^{\circ} \mathrm{C}$ で，それ以下のものでも $1400^{\circ} \mathrm{C}$ で，ほとん
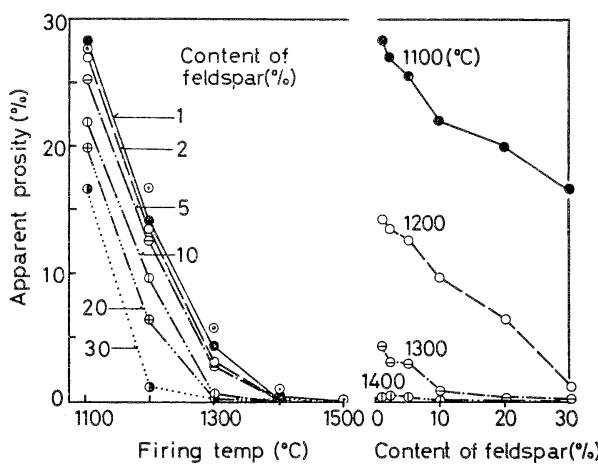

Fig. 14. Apparent porosity of the fired specimens consisting of kaolin and feldspar. 
ど0となる。

結局，いずれの素地も焼成温度の上昇とともに収縮 率, 嵩比重が増大し, 見掛け気孔率は減少し, 焼き締り が進む。この傾向は長石配合量の多い素地ほど著しい。 しかし $1500^{\circ} \mathrm{C}$ になると逆に収縮率も嵩比重も減少し， 明らかに過焼成状態となるが，この傾向もまた長石配合 量の多い素地の方が著しいことがわかった。

\section{2 組成鉱物および微構造組織の变化}

a） X線回折法による組成釷物の変化

長石索配合した素地の焼成試験片の組成鉱物をX線回 折法によって検討した結果， $1100^{\circ} \mathrm{C}$ で認められるのは， 長石のほか，クリストバライトとムライトで，長石は $1100^{\circ} \mathrm{C}$ ですでに僅かしか認められない位に減少してお り， $1200^{\circ} \mathrm{C}$ になると認められなくなる。クリストバう イトはいずれの素地にも極くわずかしか認められず，少 くとも $1400^{\circ} \mathrm{C}$ になると全く認められなくなる.ムライ トの含有量については, その (110) の回折ピークの強さ を，内部標準として $10 \%$ 配合した $\mathrm{BaCO}_{3}$ の (111) 回 折ピークの強さと比較してその量的変化を算出した. 四 -15 はその結果を示したものであるが，長石配合量の少 ない素地では $1400^{\circ} \mathrm{C} ， 5 \%$ 以上の素地では $1200^{\circ} \mathrm{C}$ ま で，それぞれ焼成温度の上昇とともにムライト量は増加 するが，それ以上の温度では涂変化しなくなる。また $1200^{\circ} \mathrm{C}$ 以上の温度で焼成した場合には長石配合量の多

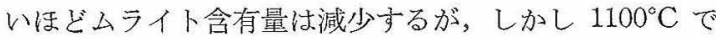
焼成した場合には，長石配合量が堌加しても，結局力オ リン配合量が減少してもムライト含有量がほとんど変化 せず，むしろ幾分増加する 傾向のあることが注目され る、低温度範国においては，長石がカオリンのムライト 化を促進することが推定される。

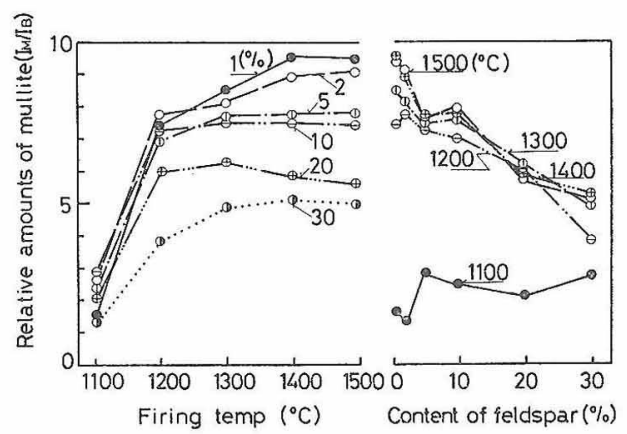

Fig. 15. Mullite content of the fired specimens consisting of kaolin and feldspar.

\section{b) 偏光顕微鏡観察}

次に素地の組成鉣物や組織の変化を検討寸るため, 各 焼成試験片の薄片について偏光顕微鏡観察を行なった。 図-16 は1例としてカオリン 70\%，長石 30\% 素地に ついての顕微鏡写真を示したものである. $1100^{\circ} \mathrm{C}$ に焼 成した素地ではカオリン部分は低複屈折の微粒子の集合
状で，この中に，大きな長石粒子は周囲が幾分熔ける位 で複屈折や双晶を保っているが，小さな粒子は全く熔け て点々とガラス粒子となって分布している. $1200^{\circ} \mathrm{C}$ に なると長石はほとんど熔けてガラス化し，またマトリッ クス中に不規則に伸びた象裂が少数認められるようにな る. $1300^{\circ} \mathrm{C}$ になるとほとんどの長石がラスがマトリッ

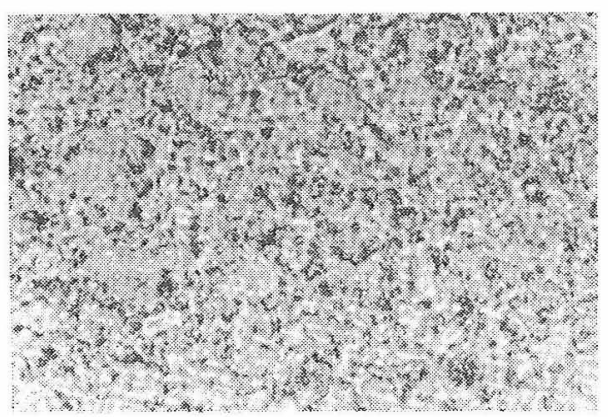

(a) $1200^{\circ} \mathrm{C}$

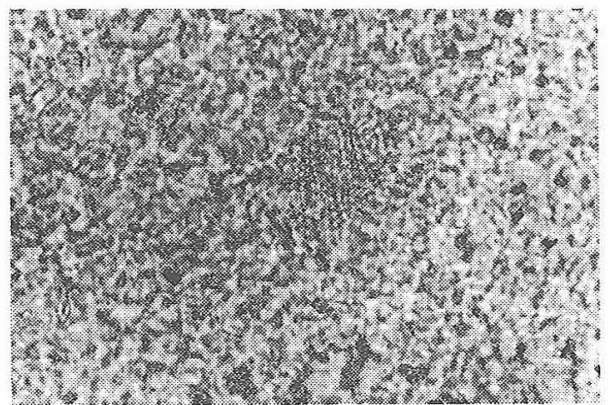

(b) $1300^{\circ} \mathrm{C}$

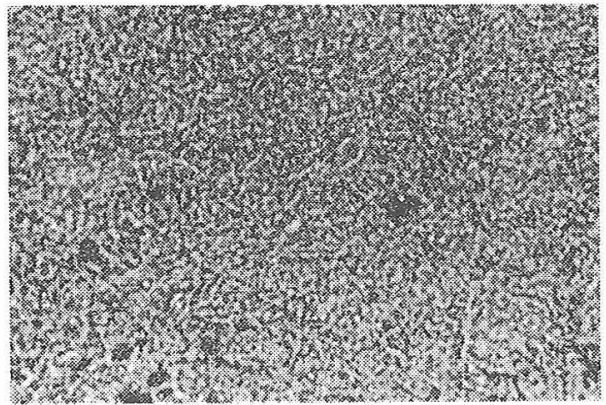

(c) $1400^{\circ} \mathrm{C}$

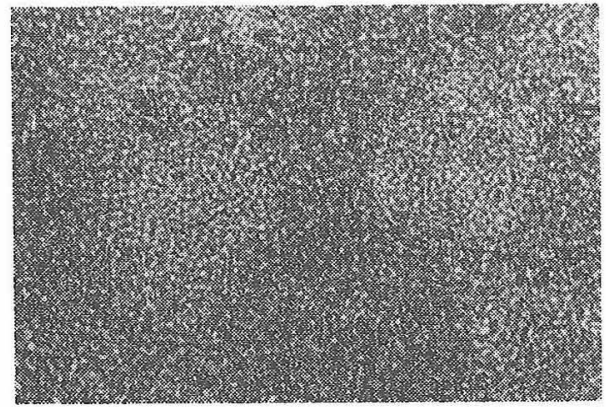

(d) $1500^{\circ} \mathrm{C}$

Fig. 16. Polarization microphotographs of the fired specimens consisting of $70 \%$ kaolin and $30 \%$ feldspar. $(\times 500)$ 
クス中に拡がりはじめ，そのため相当にガラス化したカ オリン部分には，高複屈折のムライトと思われる微結晶 が相当に発達し，同時に丸味のある気泡も認为られるよ うになる. $1400^{\circ} \mathrm{C}$ になってもこのような変化が継続し， 素地全体が次第に均質になってくるとともに刍裂状のも のも丸味を帯びて太くなり，気泡も幾分大きくなる。さ らに $1500^{\circ} \mathrm{C}$ に焼成した素地では長石配合量によって異 なるが，全体にムライト結晶が発達し，特に長石量の多 い素地では素地全体が均質にガラス質となるため，ムラ イトも素地全体，一様に数 $\mu$ 加ら $5 \mu$ 位に発達する. さらに丸味のある気泡も大きくなるが，これも長石配合

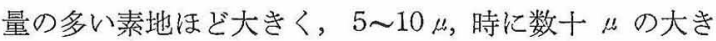
さに達している，しかし数は逆に幾分減少する傾向があ る.

\section{c）走查型電子顕微鏡観察}

さらに焼成素地の細部の組織変化を検討子るため, 試 験片の破面を走查型電子顕微鏡で観察した。図-17 はカ オリン $80 \%$ ，長石 $20 \%$ 素地についての二次電子線像 を示したものである. $1100^{\circ} \mathrm{C}$ 焼成の素地ではまだ全体 に粗い組織を示しているが，部分的に綌融物が生成して いるように思われる丸味を帯びた部分が，長石配合量の 多い素地ほど多くなる． $1200^{\circ} \mathrm{C}$ になると相当に維密に なるとともに，空隙は大部分数 $\mu$ 大の閉塞気孔となる. $1300^{\circ} \mathrm{C}$ になると素地急に均質化して緸密になり，閉 塞気孔はやや大きくなるとともに丸味を帯びるが，数は 急速に滅少し， $1400^{\circ} \mathrm{C}$ になるとさらに均質になり，気 孔も減少するようになる。図 -18 は $1400^{\circ} \mathrm{C}$ に焼成した 素地の気泡中に発達しているムライトと思われる針状結 晶である。一見気相で発達したよらにも考えられるが， 針晶の闍にガラス質が付着しているように見えることか ら，一度長石質熔融物中に針状のムライト結晶が発達し た後，例えば近くにあった気泡が急に大きくなるなどの 作用の結果，熔融物が追い出されれ 後に大きな針状結晶 の夕が残ったものではないかと推定される．Lundin も 透過型電子顕微鏡によって同じような状態を観察してい る ${ }^{5}$ 。また図-19 は $1500^{\circ} \mathrm{C}$ に焼成した素地を弗酸処理 してガラス質を除いたものの電子顕微鏡写真であるが， 素地中に縱横に針状のムライト結晶が発達しているのが わかる。

\section{3 考察}

前章で述べた収縮に引繶き起る，この段階での収縮は 著しく急激で，焼き締りの度合も急速に大きくなる。 $1100^{\circ} \sim 1200^{\circ} \mathrm{C}$ の温度範囲ではX線的にクリストバライ ト，ムライトが認晾られるほか，X線的にも顕微鏡的に も長石が減少すること，偏光顕微鏡下ですでに少量では あるがガラスの存在が認められ，その量は長石配合量の 多い素地ほど多くなっていることなどから，この温度範 囲ではをすをす多量の熔融物が存在していることがわか

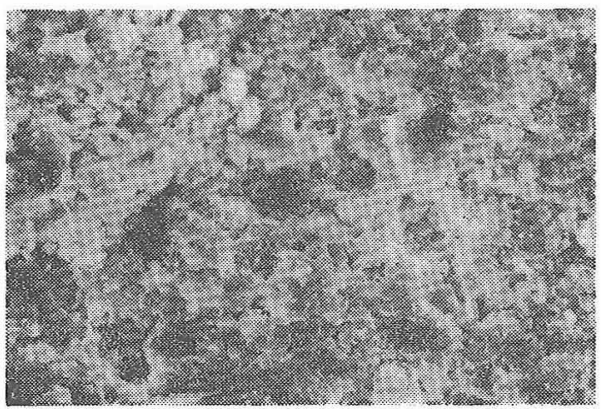

(a) $1100^{\circ} \mathrm{C}$

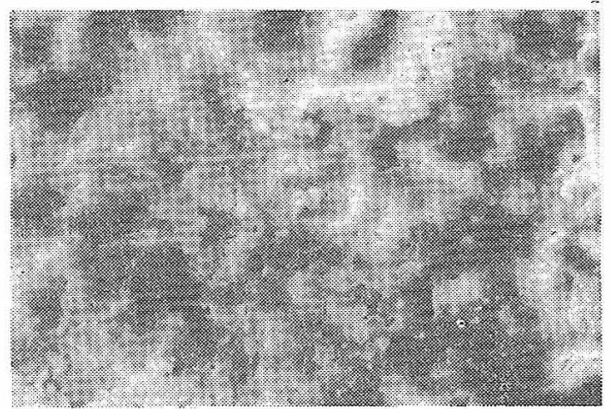

(b) $1200^{\circ} \mathrm{C}$

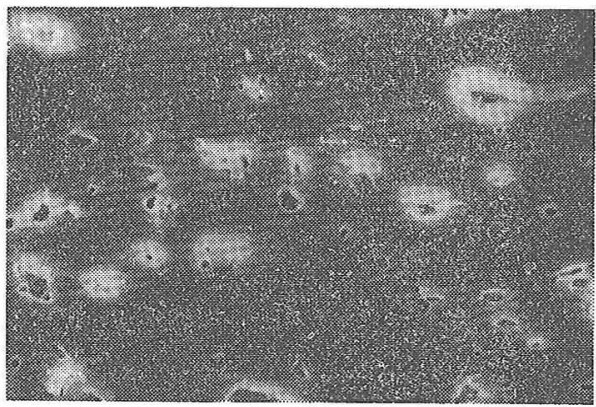

(c) $1300^{\circ} \mathrm{C}$

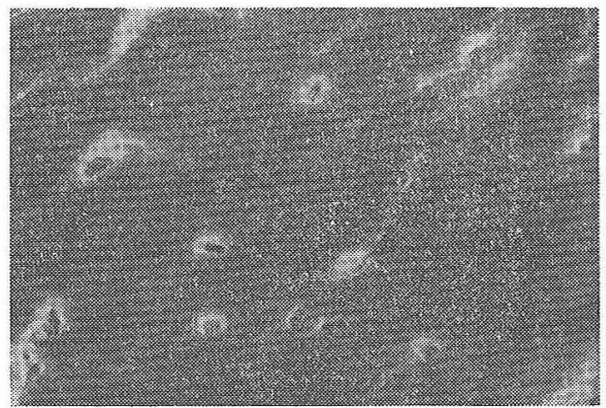

(d) $1400^{\circ} \mathrm{C}$

Fig. 17. Scanning electron microphotographs of the fired specimens consisting of $80 \%$ kaolin and $20 \%$ feldspar. $(\times 900)$

り，この段階での急激な収縮も，前段階と同じように， これら熔融物の存在による粘性流動的な繳密化にともな うものであるうと推定される。1200〜 $1300^{\circ} \mathrm{C}$ でムライ 卜量は増加するが，クリストバライトは㥛く少量のみで あり，長石は全く熔けて認められなくなる。そのため長 石配合量の多いほど熔融物の量が多くなり，をたその粘 


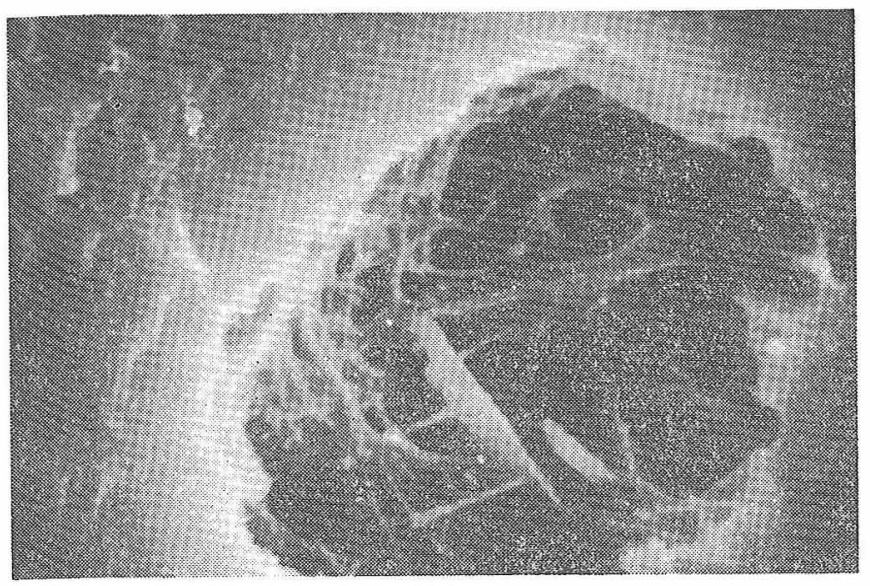

Fig. 18. Scanning electron microphotograph of mullite needles developed in void of the specimen consisting of $70 \%$ kaolin and $30 \%$ feldspar, and fired at $1400^{\circ} \mathrm{C} .(\times 9000)$

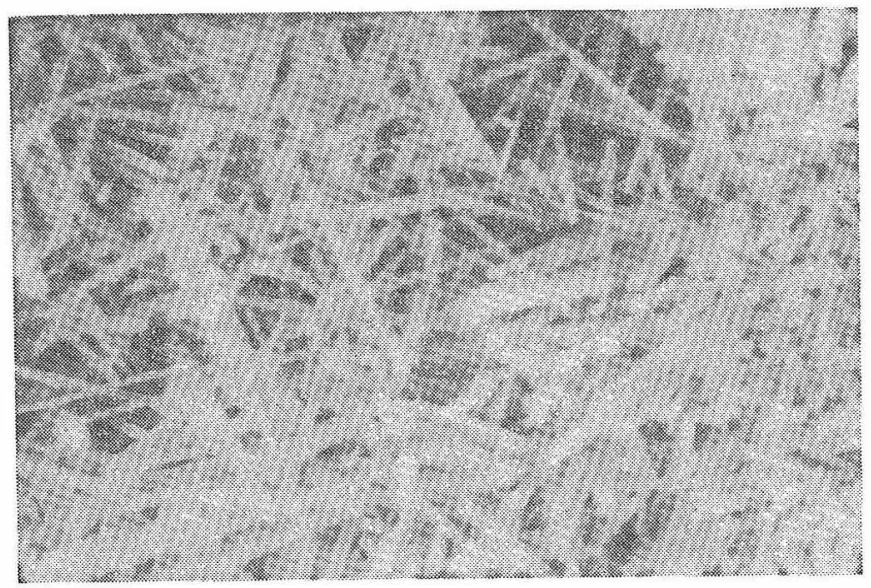

Fig. 19. Scanning electron microphotograph of the specimen consisting of $70 \%$ kaolin and $30 \%$ feldspar, fired at $1500^{\circ} \mathrm{C}$ and etched with HF. $(\times 4500)$

性なども低くなるため，維密化が促進され，30\% 配合 の素地では $1200^{\circ} \mathrm{C}, 20,10 \%$ 配合のものでは $1300^{\circ} \mathrm{C}$, $5 \%$ 以下の素地でも $1400^{\circ} \mathrm{C}$ になると，ほとんど見掛気 孔率 0 となる。

見掛気孔率がほとんぞ 0 になると素地中の空隙はいず れも関塞気孔となり，温度上昇とともに厹味を带びた， 幾分大きなものとなり, 数は徐々に減少方る.このよら な状態となると，それ以上の緻密化は停滞寸る上うにな る. $1300^{\circ} \sim 1400^{\circ} \mathrm{C}$ 以上になってもムライト量はほとん ど変化しないが, 結晶は次第に成長する.

さらに $1500^{\circ} \mathrm{C}$ になると, 線收縮率, 訔比重が逆に小 さくなり，気孔の数は減少するが，大きさは急速に大き くなり,さらに試験片の表面にも明らかに発泡が認めら れるようになるなど，素地は過焼成状態となる。このよ らな傾向は長石配合量の多い素地ほど著しいが，これは このような素地ほど熔融物の量が多く，また見掛けの粘 性も低いため, 気孔の膨脹, 合体が起り易くなるためと
思われる。

\section{8. 総 括}

陶磁器素地の焼き締り過程学定量化する基礎 資料を得ることを目的として，カオリン一長石 系素地の焼き綃り過程を，等温収縮の測定によ る速度諭的な面と，烧き締り度合と微構造的な 面とから検討した。支ず燒き締りの変化を概略 検討するために行なった界温熱膨脹収縮の測定 から，この素地もカオリン単味やカオリン一石 英系素地之同樣に, $500^{\circ} \mathrm{C}$ 付近, $900^{\circ} \mathrm{C}$ 付近沶 よび $1100^{\circ} \mathrm{C}$ 以上の 3 段階にわかれれた顕著な収 縮索示すことを認めた. $500^{\circ} \mathrm{C}$ 付近で起る収縮 はカオリン鉱物の分解に由来するるのと考えら れ, 長石配合量の多くなるほど収縮を起すカオ リン量が減少するため, 素地の収縮宣は小さく なる。

$900^{\circ} \mathrm{C}$ 付近で起る収縮壮, メタカオリン粒子 の粒界拡散による焼結にともならものと推定さ れ，その機構は長石粒子の存在によって変らな いと認められた．しかしこの収縮過程に対玄る 見掛けの活性化エネルギーは長石配合量が多く なると大きくなる、この傾向は石英添加の場合 と同じで，長石粒子がメタカオリン粒子關の桩 散を阻害することに関係するものと推定した。 また $900^{\circ} \mathrm{C}$ における収縮速度定数は長石配合 量が多くなるほど急隇するが，これは拡散を起 こすメタカオリン嘿の減少によるものと思われ る.

$1100^{\circ} \mathrm{C}$ 付近で起る急激な収縮は，カオリン 中の不純物によって生ずる熔融物と長石微粒子 の，多分メタカオリン部との共融による熔融物との存在 に主として関係する粘性流動的な維密化によるものと推 定され，この過程に対する見掛けの活性化エネルギー は，長石量が多いものでは相当に大きくなる。これは長 石の熔融が温度が高くなるほど急速に增加することによ るものと思わ机た． $1060^{\circ} \mathrm{C}$ における速度定数も長石配 合量が多いほど大きくなるが，これも長石粒子が多いほ ど生成する熔融物の量が多くなることに関㮇するものと 推定される.

さらに $1100^{\circ} \mathrm{C}$ 以上の高温度で起る急速な収縮む，ま すます増加する長石質熔融物による粘性流動による緻密 化によるものと推定される。しかしこの急激な収縮も素 地中の気孔が閉塞された状態になると急に遅くなり，ほ とんど停止するようになる。 $1500^{\circ} \mathrm{C}$ の高温度になると ガラス質になった素地中に含忠れていた気泡が互いに合 体し，数は少なくなり，また急に大きく膨脹し，さらに 発泡し, 過焼成状態になる。この傾向は長石配合量の多 
い素地ほど著しい，さらにこれらの緻密化過程での組成 鉱物や微構造組織の変化について説明した.

本研究の実施にあたって大倉和親記念財団の研究助成を得た とと它記し感謝の意を表します。また原料をで提供下さいまし た鳴海製陶（株），研究の遂行にあたって種々ご協力下さった東 京工業大学助手 秋山 豊氏, 浅賀喜与志氏, 田村信一氏, 大 塚 正氏，その他研究室の方々に感謝の意を表します。

\section{文献}

1) 浜野健也，李 應相，窯協 80 [3] 93-104 (1972).

2）李 應相, 浜野健也, 窑協 80 [10] 405-416 (1972).

3) Y.I. Frenkel, J. Phys. (USSR) 9, 385 (1945).

4）浜野健也, 窒協 67 [6] 208 (1959).

5) S.T. Lundin, "Studies on Triaxial Whiteware Bodies", Almqvist \& Wiksell, Stockholm (1959) p. 197.

(4/15/1972 受付) 